\title{
The good, the bad and the ugly
}

\section{Shaun McCann ${ }^{1}$}

Received: 30 April 2018 / Accepted: 1 May 2018 / Published online: 1 August 2018

(c) Macmillan Publishers Limited, part of Springer Nature 2018

'And so from hour to hour, we ripe and ripe, and then, from hour to hour, we rot and rot; and thereby hangs a tale'.

William Shakespeare. ('As you like it').

As a haematologist I have spent most of my life treating leukaemia either with chemotherapy or stem cell transplantation, and one of my constant worries, like yours, was systemic fungal infection in transplant recipients. As a haematologist I did not realise that the majority of my time would be spent in the diagnosis and treatment of infectious diseases. The diagnosis of systemic fungal infection is difficult and a high level of suspicion is essential. Even today there are no good, reliable diagnostic tests for systemic fungal infection, and treatment, which is expensive and sometimes toxic, is often initiated on the basis of a high index of suspicion. Although autopsy data suggest that systemic fungal infection is common in patients treated for leukaemia and related diseases this observation may overstate the frequency of such infections. It is undoubtedly true that some patients are over treated but failure to initiate early treatment may be catastrophic [1]

Shaun McCann

shaunrmccann@gmail.com

1 Haematology Emeritus, University of Dublin Trinity College, Dublin, Ireland

\section{Botrytis Cinerea}

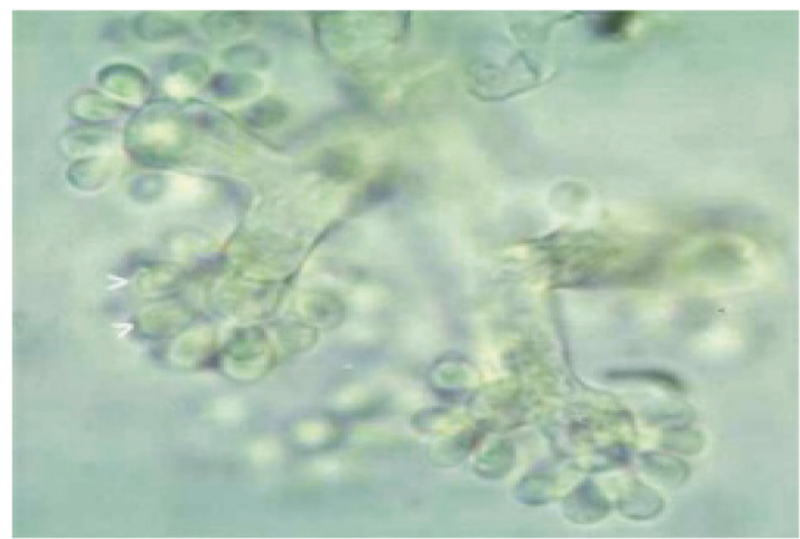

Château d'Yquem, Bordeaux

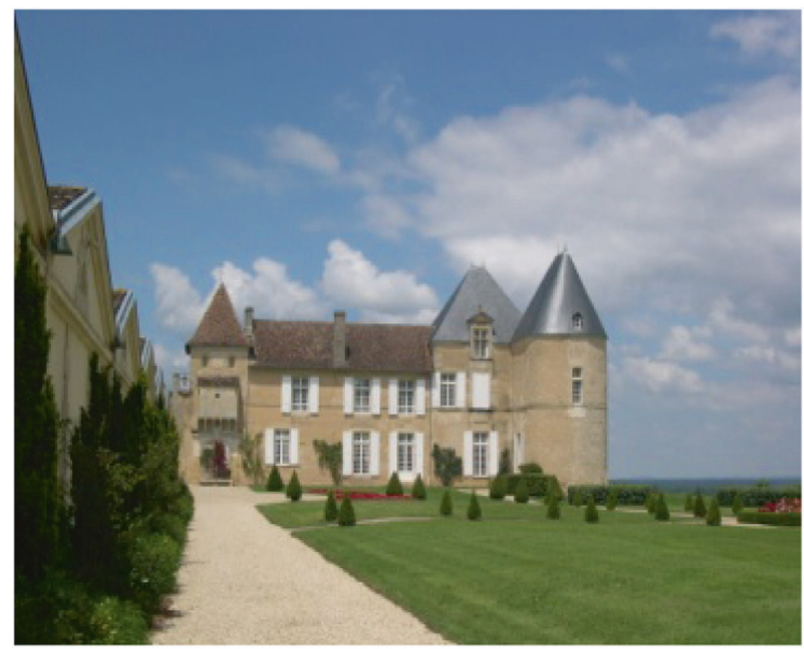

But haematologists are not the only people to worry about fungal infections: wine makers also worry. Have you ever noticed a lone rose bush standing guard at the start of a row of vines? It is a common enough sight in many European vineyards but, appendix-like, it is a vestigial earlywarning system against vine infection. It dates back to a time when the only way to detect the threat of fungus was based on the fact that it appeared on roses before vines. I do 
not think it was ever very useful, though, because by the time infection was detected on the roses it would most likely have been too late to do anything. Today there are more sophisticated means of diagnosis but the custom of planting roses endures for aesthetic and historical reasons.

Wine farmers work hard to prevent fungal infection in grapes, spraying with copper and sulphur-based sprays but like haematologists a knowledge of the prevalent fungus is helpful when choosing a specific fungicide. Fungicides can be used to either prevent or treat fungal diseases. Care must be taken, however, not to kill the yeast on the grape skin as its interaction with sugar in the grape during fermentation that produces alcohol.

However not all fungal infection is harmful. The grey fungus called Noble Rot by the English, Pourriture Noble in French, Edelfauile in German and Moffa in Italian is caused by Botrytis Cinera. This fungus can be devastating to red grapes but is also responsible for the beautiful sweet wines from Bordeaux, Hungary and Slovakia. These are called botritysed wines and probably originated in Hungary in the 16 th or 17th centuries. In Bordeaux the fungus attacks the semillon grapes while in Hungary and Slovakia it attacks the furmint grapes. The fungus punches holes in ripe grapes which results in loss of water and an increase in sugar content. The most famous sweet wines are Sauternes from Bordeaux and Tokaji from Hungary and Slovakia. The most well known vineyard in Bordeaux is Château d'Yquem and their wines fetch high prices.

The method of making Tokaji sweet wines is unique to Hungary. Tokaji Aszú (Aszú are grapes that are infected with Botrytis) are only made in years when noble rot is prevalent during warm and moist conditions. The grapes are hand kneaded and added in quantities known as puttonyos $(25 \mathrm{~kg})$ to a one year old Tokaji must. The eventual sweetness of the wine depends on the number of puttonyos added to the barrels known as gönci (136-1401). The wine is then aged in oak for at least 3 years and the bottled wine is traditionally kept upright.

I cannot think of any beneficial fungal infection in humans but wine farmers love or hate fungal infection depending on the type and the circumstances. I was always bemused when asking medical students how women got vaginal candidiasis. Answers varied from toilet seats to open windows. When I told them that vaginal candidiasis was derived from the GUT this was often recieved with disbelief. Recent research, however, on the human biome, including the mycobiome may allow new ideas about disease mechanisms and therapy of fungal infections in neutropenic patients [2].

\section{References}

1. McCann S, Byrne JL, Rovira M, Shaw P, Ribaud P, Sica S, et al. Infectious Diseases Working Party of the EBMT. Outbreaks of infectious diseases in stem cell transplant units: a silent cause of death for patients and transplant programmes. Bone Marrow Transplant. 2004;33:519-29.

2. Sam QH, Chang MW, Chai LYA. The fungal mycobiome and its interaction with Gut Bacteria in the Host. Int J Mol Sci. 2017; https://doi.org/10.3390/ilms18020330

Shaun McCann is Professor Emeritus of Haematology and Academic Medicine at St James' Hospital and Trinity College Dublin. Ireland. He lives between Dublin and Tuscany. He has written a monthly wine article for the Irish Medical Times for over 18 years under the 'nom de plume' Giovanni Morelli. 